\title{
Kur tev sāp? - Where does it hurt? Location and impersonal predicates referring to body parts in Finnish and Latvian
}

\section{Kur tev sāp? - Kermeña dalıs, vieta un bezpersonas predikāti somu un latviešu valodā}

\author{
Marja Leinonen \\ University of Helsinki \\ E-mail:marja.leinonen@kolumbus.fi
}

This article describes the non-canonical syntactic constructions of NPs and third person singular verb forms that express physical sensations, typically pain, in a certain body part. The starting point is Finnish, where impersonal constructions with NPs in the partitive or local cases form the centre of this semantic field. The test sentences, stemming from typological research material, are compared to their equivalents in Latvian. The results show that in Latvian, the nominative predominates, although locatives are used as well. Of the immediate linguistic neighbours of Latvian, Estonian follows the same strategy, while Lithuanian verbs of pain, which have received much attention, resort mostly to accusatives and locatives. In the broader Finnic field, the cognate languages express this using partitive NPs, while Russian employs a great deal of body parts in the locative and accusative, but also in the nominative. If an outside influence on Latvian and Estonian is considered, German seems to be the likeliest candidate, though there as well, locatives are a natural means for expressing sensations deep within the body.

Keywords: body-part location; impersonal constructions; areal typology; Finnish; Latvian; Baltic language area.

\section{Introduction}

Typological research on verbs expressing pain evolved during the 2000s and now covers a considerable number of languages. One of them is Finnish, for which Russian linguists collected data in the form of extensive questionnaires that were filled by two Finnish linguists, Ahti Nikunlassi and myself. One result of this work is an article by the former (Nikunlassi 2013). For Latvian, no comparable study has been conducted thus far. The aim of this paper is to fill the gap for the part of constructions resorting to impersonal predicate verbs. In both Finnish and Latvian, impersonal (third person singular) verb forms are used to signify physical and mental sensations or states that are located in specific organs of the human body. Most of the sensations concerned are indeed so-called pain verbs, but less unpleasant sensations can be coded this way as well. The Finnish corpus contained over forty verbs of the former type, while the latter, e.g. 'ears tickling', 'eyes being dazzled', 'skin being chafed', were not included at the time (Leinonen, MS). In this paper, the semantics and syntax of the relevant structures in these languages will be compared. The theoretical basis is the framework of the abovementioned research, prior research in Finnish linguistics, and subsequent research 
on Lithuanian, with one exception: defining the semantic role of the body part as stimulus (Reznikova et al. 2012; Holvoet 2016, 104) does not feel intuitively convincing, at least when it is non-nominative. The empirical basis is our data (AN \& ML) along with additional data from Finnish websites, a Latvian electronic corpus (The Balanced Corpus of Modern Latvian (Lïdzsvarots mūsdienu latviešu valodas korpuss, available at www.korpuss.lv)), and a questionnaire presented to native Latvians speakers residing in Finland. In addition, the constructions are compared with the languages of the Baltic region: Latvian, other Finnic languages, Lithuanian, Russian, and German.

\section{The constructions for expressing verbs of pain}

In the typology of semantic case frames (Reznikova et al. 2012, 444-446), the constructions of verbs of pain consist of:

1. a body part, which can be expressed as:

a) a locative phrase: (German) Es saust mir in den Ohren 'my ears buzz', Es beisst mir in den Augen 'My eyes smart', (Russian) Kol'nulo v boku 'There was a twinge in my side';

b) the theme, or subject of an intransitive verb: (German) Mir schmerzt der Kopf 'My head aches', (Russian) U menja bolit golova 'My head aches', Vchera u menja ochen' bok kolol 'Yesterday my side smarted a lot', (Estonian) Mul pea valutab 'ibid.';

c) a stimulus, or initiator of the pain situation, the subject of a transitive verb: (Serbian) Boli me ruka (hurt.PRs.3SG I.ACC arm.NOM) 'My hand hurts me'.

2. an experiencer, which can be expressed:

a) in the dative: (German) Mir schmerzt der Kopf 'I have a headache';

b) by a possessor - an oblique object or a possessive pronoun, or a possessive construction (Russian, Estonian, above);

c) as a patient - direct object: (Serbian, above).

3. a reason, conceptualized as a causer or source:

a) causer of the sensation, expressed as a subject: (French) La lumière me fait mal aux yeux 'The light gives me pain in the eyes';

b) source, as an oblique object, or a prepositional group: (Russian) Golova bolit ot stressa 'My head aches from stress'.

\section{Finnish impersonals with body parts}

In Finnish grammar, the class of so-called impersonal verbs include, among other types, tuntemusverbit - verbs of sensation - which are separated from tunnekausatiivit, causatives of feeling, although some verbs can be used in both functions. The verbs of sensation cover both those verbs of pain that have been objects of recent research, and less serious states and processes of the organism, though they are mostly more unpleasant than not. In the following, I shall discuss both verbs of pain and verbs of other physical sensations.

The Finnish verbs of sensation to be discussed collocate with animate nouns, which co-occur with body parts of inalienable possession. The animate noun has 
the form of the possessor of the body part (adessive, partitive or genitive), and when omitted, it refers to the speaker or the implied author of the discourse. The body part is either in the partitive, which is one of the object cases in Finnish, or in a locative case (inessive, illative, elative); thus, the verb is always in the incongruent third person singular (Iso suomen kielioppi 2004, 458). The unmarked word order in Finnish clauses is theme-initial. If only the body part is expressed, it is the theme:
(1) Pä̈̈-tä
huima-a /särke-e.
head-PART
feel-PRS.3sG / hurt-PRS.3SG
I feel dizzy / My head hurts.'
(2) Jalka-a kuti-tta-a.
leg-PART tickle-CAUS-PRS.3SG
'My leg tickles/itches.'

If the experiencer-possessor is expressed, it is the natural topic and occurs clause-initially. It commonly occurs in the adessive:
(3) Minu-lla särke-e pää-tä.
I-ADE hurt-PRS.3SG head-PART
'My head hurts.'

Genitive experiencers, however, are quite rare:

(4) Voi olla, että minu-n koske-e pää-hän, koska en syö lihaa.

can be that I-GEN hurt-PRS.3SG head-ILL because I.NEG eat meat.

'It may be that my head hurts, because I do not eat meat.'

(keskustelu.suomi24.fi>Ruoka ja juoma $>$ Vegaaniruoka, 9.7.2016)

The genitive is in such cases called ,dative-genitive”, since it appears in other impersonal constructions of non-controlled states as well, cf. minun/minulla on kylmä (I.GEN/ADE is cold.NOM) 'I am cold'.

Partitive experiencers are fairly common:

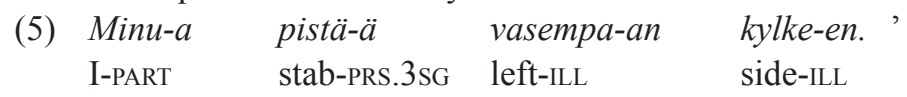

'I have a stitch in my left side.' (Nikunlassi 2013, 265)

The verbs with partitive body parts cannot be used with experiencer partitives, as intuitions do not allow two partitive arguments in the same predication: *Minua (PART) särkee päätä (PART).

Use of the local cases is dictated by the valency of the verb:

Illative:

$\begin{array}{lll}\text { (6) Minu-n } & \text { koske-e } & \text { silmi-in. } \\ \text { I-GEN } & \text { hurt-PRS.3SG } & \text { eyes-ILL }\end{array}$

'My eyes hurt.'

(quizlet.com; a study set for translating from Finnish into Russian $=u$ menja

boljat glaza 'at me hurt eyes'; 9.7.2016)

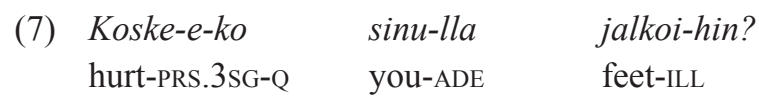


'Do your legs hurt?'

(quizlet.com; same as above, = u tebja boljat nogi? 'at you hurt legs?')

(8) Pä̈̈-hän/vatsa-an koske-e/sattu-u. head-ILL /stomach-ILL hurt-PRS.3SG

'My head / stomach hurts.'

Kylke-en pistä- $\ddot{a}$.

side-ILL sting-PRS.3SG

'I have a stitch in the side.'

Inessive:

(9) Jos

$\begin{array}{lllll}\text { korv-i-ssa } & \text { soi, } & \text { joku } & \text { ajattelee } & \text { sinua } \\ \text { ring.PRS.3SG } & \text { someone } & \text { thinks } & \text { of } & \text { you }\end{array}$

if ear-PL-INE ring.PRS.3SG someone thinks of you

'If your ears ring, someone is thinking about you.'

(mtv.fi/lifestyle/tunteet/artikkeli/...meilta-ja.../3195408, 9.7.2016)

(10) Silm-i-ssä mustene-e.

eye-PL-INE blacken-PRS.3sG

'It becomes black in my eyes.'

Elative:

(11) Sydäme-stä

otta-a.

heart-ELA take-PRS.3sG

'There is a pain in my chest.'

The case of the body part is determined by the original valence of the verb or of the specific verb construction. Some are homonyms of concrete meanings of ,touching” (koskea, sattua, pistää + illatives), while those with partitives are mostly homonyms or metaphorical extensions of transitives (särkeä 'to break') or causatives (kuti-tta- $a$ 'to tickle' < kutiaa itches' (PRS.3SG), no infinitive). In most cases, a nominative of stimulus/causer may be added, in which case the construction is close to an active sentence with a subject:

(12) (Metsä on täynnä elämää, välistä oikein)

wood is full life-PART, sometimes really

korv-i-a särke-e kaikki se meteli ja riekkuminen.

ear-PL-PART hurt-PRS.3SG all that noise.NOM and hullabaloo.NOM.

'The wood is full of life, sometimes my ears ache from all that noise and hullabaloo.'

(tiinanpatikointi.blogspot.com/... tossua-toisen-eteen-rengon-pääjärv.... 9.7.2016) 
Less often, the stimulus is in the elative:
(13)

$\begin{array}{lllll}\text { Jalko-j-a } & \text { alko-i } & \text { särke-ä } & \text { paljo-sta } & \text { seisomise-sta. } \\ \text { leg-PL-PART } & \text { begin-PRS.3SG } & \text { hurt-INF } & \text { much-ELA } & \text { standing-ELA }\end{array}$
'My legs began to ache from much standing.'
(www.suomisanakirja.fi, s.v. särkeä)

A three-fold valence is possible for some of these verbs; with an impersonal usage (14), a „normal” transitive construction with a partitive object (15), and an intransitive usage with a nominative subject (16):

(14) Jalko-j-a-ni

arista-a.

leg-PL-PART-POSS.1SG

be-sore-PRS.3SG

'My legs feel sore.'

(15) Hän arist-i

olkapää-tä-än.

$\mathrm{s} /$ he feel-sore-PRS.3sG

shoulder-PART-POSS.3

'He was very careful with his shoulder'. (because it was sore)

(www.sanakirja.org, s.v. aristaa)

(16) Haava

arista- $a$.

wound-NOM

feel-sore- PRS.3SG

'The wound feels sore.'

Stating that most of the verbs of pain in Finnish are impersonal Nikunlassi $(2013,257)$ classified them into basic and derived verbs. The basic verbs are not associated in native speakers' intuitions with a metaphorical transfer from other verbs - although for some, such a connection is evident. Such basic verbs include: särkeä ('hurt', < 'break'), pakottaa ('ache', < 'force'), kolottaa, jomottaa, kivistää ('ache'), vihloa ('stinging ache') + partitive; and sattua, koskea ('hurt', $<$ 'touch'), ottaa ('hurt', < 'take') + illative, the latter occurring also with elative. These meanings also allow a nominative subject-causer (see above example (12)). The derived verbs are metaphorical extensions of verbs signifying destruction or deformation, including burning, pressure, and loud noise (ibid. 265).

Certain verbs collocate with only certain body parts, e.g., kolottaa (about the bones, back), kivistää (about the head, heart), jomottaa (about the head), vihloa (about a tooth), whereas the most general verbs koskea, särkeä, sattua signify a pain anywhere in the body (Nikunlassi 2013).

There is a great variety of metaphorically based derived pain verbs. For example, for the heart: sydäntä (PART) ahdistaa, jäytää, kalvaa, pusertaa, raastaa, riipoo (all signify various degrees and kinds of continuing pain), kouristaa, riipaisee, viiltää (signify a stronger sudden pain), kylmää, jäätää, hyytää (signify degrees of a freezing sensation). Unpleasant sensations in the stomach are a multitude as well: vatsaa/vatsassa (PART or INE) kiertää, korventaa, kouraisee, kouristaa, korventaa, kääntää, myllertää, pistelee, polttaa, vääntää... (twist, grab, wring, scorch, turn, churn, prick, burn, wrench...) (Leinonen MS). 


\subsection{Nominative vs. non-nominative body parts}

In Finnish, the nominative can be used for the body part with some of these verbs in the meaning of bodily sensation: korvat soivat 'ears-NOM ring-PRS.3PL '; luut kolottavat 'bones-NOM ache-PRS.3PL'; hammas vihloo 'tooth-NOM cut- PRS.3SG'. Nikunlassi $(2013,270)$ states that only the verbs särkeä, pakottaa, jomottaa and kivistää (various ways of aching) are always impersonal. However, the situation is not stable. For example, an online dictionary gives the following example:

(17) Jala-t

leg-PL.NOM

'(My) legs begin to ache' (www.suomisanakirja.fi, s.v. särkeä)

alka-vat

begin-PRS.3PL

särke- $\ddot{a}$

According to my intuitions, there should be a partitive: jalkoja alkaa särkeä. However, the example clearly shows that the original transitive meaning of the verb is entirely lost, since the predicate verb here agrees with 'the legs', a subject that hardly can be thought of as an agent. Nikunlassi $(2013,271)$ finds such a use colloquial, and mentions only an occasional use of nominative body-part for the verb vihloa:

$\begin{array}{ll}\text { Viisaudenhammas vihloo } & \text { taas. } \\ \text { wisdom_tooth.NOM ache.PRS.3SG } & \text { again } \\ \text { 'The wisdom tooth is aching again.' } & \end{array}$

The question remains as to what this nominative should be called semantically. In the article cited at the beginning, it was called stimulus, source of the pain. To me, it seems that such a usage would simply confuse the issue, as there is also a reason/cause, usually well separate from the body part. Why not call it theme, as it would then be comparable to other non-volitional nominatives?

If the verb allows a nominative alongside the oblique case, as with soida 'to ring', the subject nominative seems to be preferred in atemporal sentences, e.g., in the definition of tinnitus:
Jokaise- $n$
korva-t soi-vat
joskus.
everyone-GEN
ears-NOM
ring-PRS.3PL sometimes
'Everyone's ears ring sometimes.' (www.tinnitusyhdistys.fi/3)

The non-nominative rather refers to a concrete sensation in a certain situation this is apparently the case with all impersonal predicates in a minimal context.

\section{Latvian}

In Latvian, comparable studies have not been conducted. The grammatical form of the body part co-occurring with third person singular has been treated in one study (Freimane 2008). Physical and mental processes and sensations or states are expressed using the possessive dative construction, the third person form (Latvian does not differentiate between third person singular and plural), and the 
body part either in the nominative (as in 20) or, in a few instances, in the locative case (as in (20) and (21)):

$\begin{array}{cl}\text { (20) Man } \begin{array}{l}\text { tumst } \\ \text { darken.PRS.3 }\end{array} & \begin{array}{l}\text { ac-is. } \\ \text { eyes-NOM.PL } \\ \text { 'My eyes go black.' }\end{array} \\ \text { (20')Man tumst } & a c-\bar{l} s . \\ \text { I.DAT darken.PRS.3 } & \text { eyes-LOC.PL } \\ \text { 'My eyes go black.' } & \end{array}$

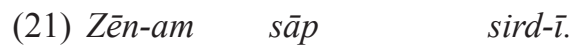
Boy-DAT hurt.PRS.3 heart-LOC
'The boy has a pain in his heart.'

According to Freimane $(2008,127,134)$, the nominative defines the location of the sensation exactly, whereas with the locative, the place of the sensation is less extensive or concretely defined: sāp kakls, mugura - kaklā, mugurā 'hurts throat. NOM, back.NOM' - 'hurts throat.LOC, back.LOC'. Apparently, the author finds that the stimulus/cause is present in the context implicitly, or it is an indefinite 'something'.

In order to investigate the usage, a questionnaire with Finnish impersonal constructions was presented for translation to three native Latvian speakers. In their answers, the nominative predominates. Support for the choices was sought in the Latvian electronic corpus in the The Balanced Corpus of Modern Latvian. Below, the results of the corpus are exemplified, if they differ from the answers of the informants:

Nominatives:

(22) Silmi-ä kirvelee, häikäisee. $=$ Ac-is grauž, žilbst.

eyes-PART smart are-dazzled eyes-NOM.PL smart.PRS.3 be_dazzled.PRS.3 'Eyes smart, are dazzled.'

(23) Käsi-ä

hands-PART

paleltaa. $\quad=$ Rok-as salst.

'Hands are cold.'

(24)

$\begin{array}{llll}\text { Hammas-ta } & \text { särkee. } \\ \text { tooth-PART } & \text { aches } & \text { Zob-s } & \text { sāp. } \\ \text { tooth-NOM } & \text { ache.PRS.3 }\end{array}$

'Tooth aches.'

(25) Kurkku-a kuristaa. = Kakl-s žņaudz-as.

throat-PART chokes throat-NOM choke-PRS.3.REFL

'Throat is tight (chokes).'

(26)

$\begin{array}{lll}\begin{array}{l}\text { Poski- } a \quad \text { polttaa. }= \\ \text { cheeks-PART burn }\end{array} & \begin{array}{l}\text { Vaig- } i \\ \text { cheeks-NOM.PL }\end{array} & \begin{array}{l}\text { deg } / \text { svilst. } \\ \text { burn/flame.PRs.3 }\end{array} \\ \text { 'Cheeks are burning/flaming.' } & \end{array}$

The constructions with nominatives were used for ,eyes going dark”, „,mouth getting dry”, ,feet tickling”, ,face feeling hot”, „head aching”. 


\section{Locatives:}

Apparently, locatives in Latvian are used for sensations that are felt within the body, as opposed to on the surface:

(27) Korva-an, kylke-en pistää. $=A u s-\bar{l} \quad$ dur, sān-ā/sān-os $\quad$ dur-as $/ d u r$. ear-ILL side-ILL stings ear-LOC sting, side-LOC/LOC.PL sting-(REFL-)PRS.3 'X stings in my ear, I have a stitch in the side.'

(28) Rinta-a pakottaa. $=$ Krūt-īs spiež/žņaudz. chest-PART aches chest-LOC.PL press.PRS.3

'My chest aches (feels pressed).' (dictionary La-Ru s.v. spiest: Man pakrūtē spiež.)

(29) Nenä-än pistelee. = Degun- $\bar{a}$ durst-ās/kņudina/kņud. nose-ILL prickles nose-LOC prick-(REFL-) PRS.3 'My nose prickles /itches.'

Several Latvian constructions were given for the following inner body sensations; the locative refers specifically to a sensation inside the body part:

(30) Sydämestä ottaa. = Sird-ī dur. heart-ELA takes heart-LOC stab.PRS.3

'I have a pain in my chest.'

(31) Korvi-ssa soi. = Aus-is/aus-īs džinkst/zvana. ears-INE ring ears-NOM/LOC.PL tingle/ring.PRS.3

'My ears tingle/ring.'

(32) Vatsa-a turvottaa, vääntää, kouristaa $=$ stomach-PART swells, turns, gripes

Vēder-s piepūties, griež.

'stomach-NOM is swollen, $\mathrm{x}$ turns my stomach'

'My stomach is swollen / x turns my stomach.'

(33) Vatsaa korventaa, kiertää. = Vēder-āadzina/griež-as. stomach-PART burns/turns stomach-LOC burn/turn-PRS.3.REFL 'I have stomach cramps.'

(34) Kurkku-a kutittaa. = Kakl-s/kakl-āaniez. throat-PART tickles throat-NOM/throat-LOC tickle.PRs.3

'My throat tickles.'

A further impersonal use was found in the bonito corpus for the verb smelgt 'to smart, to ache', with a locative:

(35) Viņam varbūt nedaudz smeldza pakrūt-ēe par

he.DAT maybe a_bit smart.PST.3 belly-LOC PREP pamestaj-iem bērn-iem. abandoned-DAT.PL child-DAT.PL 'He had a bit of a bellyache because of the abandoned children.' (Jānis Kalve. Skrīviņu sakraments 2005; www.korpuss.lv) 
An example with pulsēt 'throb':

(36) (... drēbes un āda ir vienādi pelēkas,) deniņ-os pulsē.

clothes and skin are equally pale, temple-LOC.PL throb.Prs.3

'The clothes and the skin are equally pale, the temples throb.'

(Inga Ābele. Sniega laika piezīmes 2004; www.korpuss.lv)

And for the verb kutēt 'to tickle' (cf. example (2)) above):

(37) [ceļš...] jau sašūpoja mašīnu, viegli pameta gaisā tā,

road already rocked the car, lifted lightly into the air so

ka Kic-ei nokutēj.a vēder-ā, tad...

that Kice-DAT tickle.PST.3 stomach-LOC then

'The road already rocked the car, lifted it lightly into the air, so that it tickled in Kice's stomach, then...'

(Inga Ābele. Akas māja 1999; www.korpuss.lv)

Accusatives:

There were a few metaphorical impersonals with transitive valency (ACC) retained:

(38) Henke-ä salpaa. $=$ Elp-u aizsit.

breath-PART closes breath-ACC close.PRS.3

'My breath is stopping, choking.'

(39) Luita

bones-PL.PART

kolottaa. $=$

Kaul-us

lauž.

'My bones ache.'

(40) Kurkkua

$$
\text { ärsyttää. }=
$$

bone-ACC.PL

break.PRs. 3

Throat-PART irritates

'My throat is irritated.'

In The Balanced Corpus of Modern Latvian, there are no accusative body parts with these verbs, except kaulus lauzt, which seems to be common:

(41) Man bez tām vinas drēbēm uzreiz bezmiegs

I.DAT except those.DAT her.GEN clothes.DAT.PL suddenly insomnia.NOM un kaul-us lauž.

and bone-ACC.PL break.PRS.3

'Without those clothes of hers I get suddenly insomnia and my bones ache.' (Pēteris Pūritis. Jansona istaba 2006; www.korpuss.lv)

However, an example cited in an article by Holvoet $(2016,99)$, does show an accusative:

(42) Izmeklējumi

Examinations

taču

nabadzingam

however

jāveic,

jo

poor-man.DAT

galv-u

must-make for

'An examination is needed, for the poor devil's head is torn apart.' 
Holvoet (ibid. 98-99) calls the phenomenon „demoted agent”.

Impersonal sentences without the body part are used with these transitive verbs, often with a qualifying adverb:

(43) Citas sievietes atkal pēc operācijas saka-vai, kā sāp! Es pat other women again after operation say oh how hurt.PRS.3 I.NOM even rok-as nevaru pacel-t, kā man spiež un sāp. hands-ACC.PL not_can.PRS.1SG lift-INF how I.DAT press.PRS.3 and hurt.PRS.3 'Some women again after operation say: Oh, how it hurts, I cannot even lift my hand, how it presses me and hurts.'

(Zane Nikodemusa. Vai esam silikona paaudze; www.korpuss.lv)

\section{Verbs of sensation, without body part}

Somewhere between body-part sensations and feelings are the constructions of experiencer + sensation. In Finnish, causative verbs in $3 \mathrm{SG}$ and partitive experiencers (animate, topic) replicate the productive construction of causatives of feeling, which have been the subject of research: Siiroinen (2001) has studied the derivational processes of verbs of emotions, e.g. suuttua - suututtaa 'to get angry' - 'to anger someone'. The causative with the suffix -tta- is used in the construction NP-PART + V-TTA-3SG, e.g. minua suututtaa 'I feel angry', which determines its meaning as a non-controlled feeling, attributed to the speaker (or the subject of discourse, from whose point of view the narrative develops) (Siiroinen 2001, 168). This extremely productive means of impersonalization can base its correlation on verbs, nouns and adjectives as well. Similarly in our case, the verbs of physiological sensations are correlated with (if not directly derived from) verbs or nouns of the same root:

(44) Minu-a nuku-tta-a.

I-PART sleep-CAUS-PRS.3

'I feel sleepy.' (< nukkua 'to sleep', nuku-tta-a 'put to sleep')

The model also applies to such physiological sensations as 'yawning' (haukotella - haukotuttaa/haukottaa), 'hiccupping' (nikotella - nikottaa), 'laughing' (nauraa - naurattaa), 'crying' (itkeä - itkettää), 'being thirsty' (< jano 'thirst') janottaa, 'being hungry' (< nälkä 'hunger') nälättää, 'being nauseous' oksentaa - oksettaa, etc.

There are other verbs for sensations for which a derivational relationship is harder to find, such as hiukoa/hiukaista 'to feel hungry', huimata 'to feel dizzy', yököttää, ällöttää, kuvottaa 'to feel nauseous', etc.

In Latvian, the choices for constructions with the corresponding verbs of sensations are a dative-possessor either with the third person and a deverbal noun, or with an impersonal reflexive verb and the infinitive:

$\begin{array}{rlllll}\text { (45) Man } & n \bar{a} k & \text { miegs. } & \text { Man } & \text { grib-as } & \text { gule- } t \text {. } \\ \text { I.DAT } & \text { come.PRS.3 } & \text { sleep.NOM } & \text { I.DAT } & \text { want-PRS.3.REFL } & \text { sleep-INF }\end{array}$ 'I am sleepy.' 
Further answers of my informants to the above constructions resorted to deverbal nouns, often plurale tantum, cf. above:

$\begin{array}{llll}\text { (46) Man } \quad n \bar{a} k & \text { smiekl-i, } & \text { vemien-s, } & \check{z} \bar{a} v \text {-as, } \\ \text { I.DAT come.PRS.3 } & \text { laughter-NOM.PL } & \text { vomiting-NOM } & \text { yawning-NOM.PL } \\ \text { drebul-i, } & \check{z} a g \text { - } a \text { s. } & & \\ \text { shudders-NOM.PL } & \text { hiccups-NOM.PL } & & \end{array}$

'I feel like laughing, vomiting, yawning, shuddering, hickuping.'

For a few basic sensations, there are specific impersonal verbs:

(47) Man salst, slāp-st.

I.DAT freeze.PRS.3 thirst-PRS.3

'I am cold, thirsty.'

Both physical and psychological conditions are expressed using impersonal verbs with experiencer datives, but the causer/stimulus is in the nominative: riebties 'to loathe', dergties 'to be disgusted with sth', sāpēt 'to ache', smelgt 'to smart', šķist 'to seem', veikties 'to succeed, to have luck', patikt 'to please', rūpēt 'to be worried about sth', gribêties 'to feel like doing sth.', etc.

The experiencer dative is also used with the copular verbs but 'to be', tikt 'to become', tapt 'to become', klūut 'to become' and adverbs: berrnam ir bail 'the child is afraid', slimniekam klu usst labāk 'the patient is getting better', klausìtājiem bija interesanti 'it was interesting for the listeners'.

\section{Neighbouring languages}

\subsection{Baltic: Lithuanian}

Unlike the corresponding constructions in Latvian, constructions with verbs of pain in Lithuanian have drawn the attention of several linguists. The obvious reason is the present heightened interest in oblique participants.

The Finnish PART + V construction appears to be similar to the Lithuanian construction. The possessor-dative is used in Lithuanian to encode the animate experiencer of the sensation. The verb is monopersonal third person, and the body part is usually in the accusative, or in some dialects in the nominative (Bjarnadóttir 2014, 9-10).

Standard Lithuanian:

(48) Man

$$
\text { skauda galv-a. }
$$

I.DAT ache-PRS.3 head-ACC

'I have a headache.'

Modern Lithuanian dialect:

(49) Sopa

$g i$

hurt.PRS.3 PARTICLE

'It hurts everywhere.' vis-i gal-ai.

all-NOM.PL end-NOM.PL 
In Old Lithuanian texts, the nominative is the main case used:

(50) Sópa gatwa[...] skaûst ingstai.

hurt.PRS.3 head-NOM hurt.PRS.3 kidney-NOM.PL

'Head is hurting $[\ldots]$ kidneys are hurting.'

A locative or prepositional phrase is also possible (Seržant 2013, 190):

(51) Man

skauda

šon-e.

I.DAT

ache.PRS. 3

side-LOC

'It hurts in my side.'

The case frame dative - accusative is unique in Lithuanian for this semantic group of verbs, comprising two types of verbs. First, there are pain-specific verbs, which can be used without naming the body part. The dative denoting the affected person is licensed by the verb itself.
Ligoniui
skauda.
patient.DAT
hurt.PRS.3
'The patient is in pain.'

The second group is called derived pain constructions. The number of such verbs denoting pain is high. For 'aching', Bjarnadóttir lists 45 verbs (with derived senses, covering the various complaints given above for Finnish - no doubt closer scrutiny would produce just as much in Finnish dialects), and 4 verbs for 'itching'. Some are rare, dialectal or archaic. Obviously, this semantic field is important, and the pattern is productive. The common factor is ,physiological inconvenience".

The sources of the derived pain verbs denote pricking, butting, poking, sticking, planting, digging down, biting, cutting, cleaving, splitting, slicing, peeling, tearing, gnawing, eating, prodding, hulling, shelling, burning, squeezing, pinching, screwing, breaking, hitting, and dragging. The characterizations for the Finnish verbs, „destruction, deformation, pressure”, would no doubt cover most of them. Metaphorization, and conceptualization of the construction as a state or a condition are probably applied universally. For this purpose, the pain-specific verbs are suitable, whereas the derived pain verbs may be better suited to denoting a pain that occurs once and then passes (Bjarnadóttir 2014, 13).

Lately, three other linguists have turned their attention to the pain verb constructions of Lithuanian, with varying theoretical descriptions and opinions on which construction is the original one. As Bjarnadóttir (2014) explained, Holvoet (2013) refers to the Obliqueness Hierarchy: accusative marking on the body part is due to an obliqueness adjustment, as an intransitive subject next to a dative argument (with certain subject properties) creates a mismatch, which is resolved by introducing the accusative. Seržant (2013) explains the accusative in terms of a more general drift from a non-canonical nominative object towards a canonical accusative-marked object. The drift is supported by the impact of the originally causal pain verb type (e.g., durti 'sting'). Piccini (2008) argues that the accusative marking of body parts is the original case, and that the nominative is an innovation the dative is not an experiencer but an external possessor, and the body part is the 
experiencer and subject in the construction. She compares the construction with accusative experiencers in other constructions.

Bjarnadóttir (2014, 7-8) argues that the correct approach is Construction Grammar, where we find a lexicon-syntax continuum in which every part is treated as a construction. It is a symbolic unit, an association of structure and meaning. Since there is variation between nominative and accusative body parts in dialects and Old Lithuanian, Bjarnadóttir finds that the derived, originally transitive verbs serve with their accusative objects as a source construction for extension, thus retaining the accusative in the new meaning as well. The accusative, which Bjarnadóttir calls subject, may even be extended to the sphere of pain-specific verbs, which originally collocated with nominative subjects. Thus, the solution is similar to that of Seržant's, though sidestepping the idea of canonical forms. Extension, metaphorization, and productivity of language are the key concepts here. Besides, more general suggestions fail to explain why this extension concerns only verbs of pain and not other semantic fields.

\subsection{Finnic and Finno-Ugric languages}

The Finnish constructions have a possessor-adessive (less frequently genitive) to whom the inalienable body part belongs, while the body part is marked either with the partitive - the prototypical object case of durative processes, - or locative case with the case frame having been inherited from the original concrete verb. The causer-reason, if present, occurs in the nominative or the elative. In closely related Finnic languages, the situation varies somewhat.

Estonian does not fully resort to the impersonal frame, although partitive experiencers and causatives of feeling belong to the basic experiencer sentence models. Thus, the body part occurs in the nominative: Mul pea valutab I.ADE head.NOM hurt.PRS.3SG 'My head aches.' The causer is a normal source (elative) or subject (nominative): pea valutab suurest lärmist (head.NOM hurts big.ELA noise. ELA) 'My head aches from the big noise', or suur lärm paneb pea valutama (big. NOM noise.NOM makes head.ACC hurt.INF) 'The big noise gives me a headache' (Helle Metslang, p.c.). However, locative cases are also used, just as in Finnish and in Latvian. Rätsep $(1978,78,107)$ lists the sentence models of Estonian, and in the group LOC $+\mathrm{V}$, in addition to meteorological verbs, there is the only case of ,physiological inconvenience” süda iiveldab or iiveldab (heart.NOM sickens / sickens) 'I feel sick, like vomiting'. In the group (N-NOM) + V there are the examples südame all pööritab (heart.GEN below dizzies) 'I feel dizzy'; rinnus pistab (chest.INE stabs) 'There is a stabbing in my heart'; kõrvus kumiseb (ear.INE hums) 'My ears are humming'. The dictionary shows such examples as ihus pistis (skin.INE prickled) 'My skin prickled', kõris pitsitab (throat.INE constricts) 'My throat is constricted', südame alt pigistab (heart.GEN below tightens) 'It tightens below my heart' (SVSSK 2003 s.v. pistää, pistellä, kuristaa, ahdistaa).

In North-East Estonian dialects, which have had contacts with the more eastern Finnic languages, e.g., Votic and Finnish, the body part appears in the partitive: päa kivistä (head.PART aches) 'I have a headache' (cf. Finnish päätä kivistää, ibid.), sütand valutta (heart.PART hurts) ibid. (Must 1987, 288; Lindström 2012, 33). 
Votic employs the partitive body part with adessive experiencer: Мілл vajvettaB vattsa (I.ADE hurts stomach.PART) 'My stomach hurts' (Markus, Rožanskij 2011, 222).

Vepsian has taken the transitive model to the utmost, with the body part in the genitive, the case of the total object: hibjan sibitav (skin.GEN itches) 'My skin itches', minei kohtun kibištab (I.ADE stomach.GEN hurts) 'My stomach hurts' (Grünthal 2015, 67, 255, 262: „cognitive-somatological verbs of feeling”; a usage first noted in Kettunen 1943, 240-241).

Karelian shows both partitive and genitive for body parts: suonda vedelöv (vein.PART draws) 'I have a cramp', peän huimoav (head.GEN feels-dizzy) 'My head feels dizzy', hengen ahistav (breath-GEN presses) 'I am short of breath' (Ahtia 1938, 3, 11 /kaino.kotus.fi.digitointi/pdf/Ahtian_lauseoppi.pdf).

The impersonal use of verbs of pain extends even to the eastern relatives of these languages, e.g., Komi (Luchina 2011).

Livonian: The two examples in the extinct Salaca Livonian written down by J. A. Sjögren in 1846 show a nominative body part with an agreeing verb: min pää kienslu-b (ich-Genetiv-Akkusativ Kopf lärmen-PRS) 'I feel dizzy', ame- $d$ podu-b (Zahn-PL schmerzen-PRS) '(My) teeth ache' (Salis-Livisch 2016, 223, 348). Thus, Livonian has followed the model presented by Latvian and Estonian.

\subsection{Superstrate languages}

Lindström $(2012,32)$ assumes that the modern Estonian nominative bodypart construction may be due to an influence from the surrounding languages i.e. Russian, German, and Latvian, - and that the partitive construction represents an older stage. As for the causatives of feeling, which in Finnish employ the impersonal construction with partitive experiencers, e.g. Minua pelottaa (I.PART frightens) 'I am afraid', the use of the corresponding constructions in Estonian without a stimulus, e.g. Mind hirmutab (I.PART frightens) 'ibid.', feels incomplete; the stimulus here is an obligatory argument, which may have its model in Russian or German as well.

In Russian, the constructions with both the nominative and accusative or locative + V.3SG are used to express pain in a body part: spina/spinu lomit (back. NOM/ACC hurts) 'My back hurts', kol'nulo v boku (stabbed PREP side.LOC) 'There was a twinge in my side'; $u$ menja bolit golova (PREP I.GEN aches head.NOM) 'I have a headache', Vchera u menja ochen' bok kolol (yesterday PREP I.GEN very side.NOM hurt) 'Yesterday my side hurt a lot'. However, locatives for certain phenomena are fairly common, e.g. $v$ grudi davit (PREP chest.LOC presses) 'There is a pressure in my heart', $v$ gorle sadnit, peresohlo (PREP throat.LOC smarts, got dry) 'My throat smarts, has got dry', $v$ glazah temneet (PREP eyes darkens) 'My eyes become dark', $v$ viskah stuchit (PREP temples pounds) 'My temples pound', $v$ noge sverbit (PREP leg.LOC itches) 'My leg itches'. There are different degrees of acceptability for different verbs (Reznikova et al. 2012, 456). In the conceptualization of their project, Bonč-Osmolovskaja, Rahilina and Reznikova (2007) state that typically, the Russian verbs of pain are used in constructions with unexpressed or nonnominative subjects Apparently, much the same situation is found in other Slavic 
languages (Bricyn et al. 2009; cf. the articles on Ukrainian, Polish, Serbian, Croatian).

For sensations of the experiencer without the body part, the constructions of accusative $+\mathrm{V}$ and dative + predicative adverb, and dative + reflexive $\mathrm{V}$ are commonly used: ego korchit (he.ACC convulse) 'He feels convulsions', menja toshnit (I.GEN feels-sick) and mne toshno (I.DAT sickening) both mean 'I feel like vomiting', mne chihaetsja, zhevaetsja 'I feel like sneezing, yawning'.

As another candidate for the source of influence, German has also been proposed. In this language, both nominative and locative (PREP $+\mathrm{N})$ body parts are found: (with the formal subject es) es kratzt im Hals (it scratches PREP throat) 'My throat itches', mir schmerzt der Kopf (I.DAT hurts head.NOM) 'I have a headache', meine Augen beissen (my eyes.NOM bite) 'My eyes smart' (Reznikova et al. 2012, 430, 445, 450; Reznikova 2009). If a model for the nominative body part use is required, it is rather German than Russian.

\section{Conclusion}

Finnish and Latvian apply possessive constructions of esse for the experiencerpossessor which is often left implicit. The body part represents inalienable possession, and the verb is of low semantic transitivity. A third argument, cause can be present. In Finnish, the body part in partitive, an object case, is very common and productive for metaphorical expressions of pain or lesser sensations. In Latvian, nominative for the body part predominates, and the locative is used for sensations within the body - as in Finnish as well. The accusative seems to be used in very few cases for body parts. It may be assumed that in all the languages discussed, locatives can be used in subjectless constructions.

In Latvian, there is no specific productive morphological means of creating verbs of sensation, or constructions of physical sensations. Reflexive verbs with dative experiencers often correspond to Finnish causatives. Physical sensations, without body parts but with dative experiencers, are expressed using a specific construction with $n \bar{a} k t$ 'to come' and a deverbal noun.

Finnish and Lithuanian show similar strategies that deviate from the prototypical SAE Subject-Verb-Object type. In Finnish, no general verb of pain, comparable to Latvian sāpèt, Russian bolet', English ache, or German schmerzen has developed a personal usage, if we do not count the few examples with nominative subjects which can be found on the net for the verbs särke ä, kolottaa, vihloa and aristaa, possibly others as well.

In Lithuanian, the accusative plays the same role as the partitive in Finnish, when it refers to the body part with verbs of pain, and the usage appears to be just as productive.

Latvian deviates conspicuously from its Baltic neighbour by preferring the nominative, though the material is insufficient to justify any further conclusions. Is there a tendency towards canonical forms with a nominative subject in Latvian; a tendency towards one form - one meaning that is also apparent in the extension of accusative objects and nominative subjects into the sphere of former genitives with negation? Whether there was an original construction of pain verbs with accusative 
at some earlier stage is not clear, though derived transitive verbs should naturally serve as a basis for metaphorization.

Locatives for body parts without subject nominatives are used in Finnish, Latvian, Lithuanian, Estonian, Russian, German, and probably in all the rest of the Finnic and Slavic languages.

In areal typology, Latvian has been grouped together with Estonian, as they seem to have experienced certain changes that are not found in their neighbours. Stolz $(2001,604)$, who studied the instrumentals and comitatives in Circum-Baltic languages, states that the similarity of Estonian and Latvian constructions must be due to Germanicization, as Latvian and Estonian have shared the same Germanic superstrate for several centuries. That is, these neighbouring languages have not influenced each other.

\section{Abbreviations}

ACC accusative

ADE adessive

CAUS causative

DAT dative

ELA elative

GEN genitive

ILL illative

INE inessive

INF infinitive

$\mathrm{N}$ noun

NEG negative

NOM nominative

PART partitive

PL plural

POSS possessive

PREP preposition

PRS present

PST past

Q question particle

REFL reflexive

SG singular

V verb

\section{Sources of examples}

1. Ahtia, Edvard G. 1938. Karjalan kielioppi III (Lauseoppi). kaino.kotus.fi.digitointi/ pdf/Ahtian_lauseoppi.pdf.

2. Anģ̣u-latviešu vārdnīca / English-Latvian Dictionary. 2002. Rīga: Avots.

3. Bricyn, Viktor M. et al. (eds). 2009. Koncept bol'v tipologicheskom osveshchenii. Kiev: Vidavničij Dim Dmitra Burago. 
4. Grünthal, Riho. 2015. Vepsän kielioppi. Hilfsmittel für das Studium der finnischugrischen Sprachen. XVII. Helsinki: Suomalais-Ugrilainen Seura.

5. Hurme, Raija, Malin, Riita-Leena, Syväoja, Olli. 1984. Uusi suomi-englantisuursanakirja. Porvoo-Helsinki-Juva: WSOY. Available: www.ilmainensanakirja. fi/sanakirja_suomi-englanti.

6. Kettunen, Lauri. 1943. Vepsän murteiden lauseopillinen tutkimus. SuomalaisUgrilaisen Seuran Toimituksia. LXXXVII. Helsinki: Suomalais-Ugrilainen Seura.

7. Latviešu-krievu vārdnīca. Latyshsko-russkij slovar'. 2002. Rīga: Avots.

8. Lìdzsvarots mūsdienu latviešu valodas korpuss (The Balanced Corpus of Modern Latvian). Available: www.korpuss.lv.

9. Leinonen, Marja (MS). Metaphorical pain verbs and their use for emotional reactions.

10. Markus, Elena B., Rožanskij, Filip I. 2011. Sovremennyj vodskij jazyk. II. SanktPeterburg: Nestor-Istorija.

11. Must, Mari. 1987. Kirderannikumurre. Häälikuline ja grammatiline ülevaade. Tallinn: Valgus.

12. Reznikova, Tatiana I. 2009. Predikativy boli v nemeckom jazyke. Koncept bol' $v$ tipologicheskom osveshchenii. Bricyn, Viktor M. et al. (eds). Kiev: Vidavničij Dim Dmitra Burago, 154-198.

13. Rätsep, Huno. 1978. Eesti keele lihtlausete tüübid. Eesti NSV Teaduste Akadeemia, Emakeele seltsi toimetised. 12. Tallinn: Valgus.

14. Salisch-Livisch. 1. J. A. Sjögrens Manuskript. Festschrift für Jens Peter Laut zum 60. Geburtstag, Winkler, Eberhard, Pajusalu, Karl (eds). 2016. Veröffentlichungen der Societas Uralo-Altaica. 87. Wiesbaden: Harrassowitz.

15. Suomen kielen perussanakirja. I-III. 2001. Kotimaisten kielten tutkimuskeskuksen julkaisuja. 55. Helsinki: Edita, Kotimaisten kielten tutkimuskeskus. Available: www.suomisanakirja.fi

16. SVSSK = Suomi-viro-suursanakirja - Soome-eesti suursõnaraamat. I-II. 2003. Tallinn-Helsinki: Kotimaisten kielten tutkimuskeskus, Eesti Keele Instituut.

17. Vahros, Igor', Ščerbakov, Antti. 1975. Finsko-russkij slovar. Moskva: Russkij jazyk.

18. Veisbergs, Andrejs (red.). 2003. Jaunā latviešu-anglu vārdnīca / The New LatvianEnglish Dictionary. Rīga: EKLV.

\section{References}

1. Bjarnadóttir, Valgerður 2014. Emergence and spread of accusative marking of body parts in Lithuanian construction grammar account. Baltu filologija. XXIII (1), 5-28.

2. Bonč-Osmolovskaja, Anastasija A., Rahilina, Ekaterina V., Reznikova, Tatiana I. 2007. Konceptualizacija boli v russkom jazyke: tipologicheskaja perspektiva. Available: www.dialog-21.ru/digests/dialog2007/materials/html/12.htm.

3. Freimane, Inta. 2008. Trešā persona latviešu verbu sistēmā. LU Akadēmiskais apgāds.

4. Holvoet, Axel. 2013. Obliqueness, quasi-subjects and transitivity in Baltic and Slavonic. The Diachronic Typology of Non-Canonical Subjects, Seržant, Ilja A., 
Kulikov, Leonid (eds). Amsterdam, Philadelphia: John Benjamins Publishing Company, 257-282.

5. Holvoet, Axel. 2016. Argument marking in Baltic and Slavonic pain-verb constructions. Argument Realization in Baltic. Holvoet, Axel, Nau, Nicole (eds). Amsterdam, Philadelphia: John Benjamins Publishing Company, 83-106.

6. Lindström, Liina. 2012. Tundekausatiivikonstruktsioon eesti moodi. Keel ja Kirjandus. 1, 30-47.

7. Luchina, Elena. S. 2011. Konceptualizacija boli v muzhevskom govore komizyrjanskogo jazyka. Acta Linguistica Petropolitana. Trudy Instituta lingvisticheskih issledovanij RAN. VII, 3. Kazansky, Nikolai N. (ed.). Sankt-Peterburg: Nauka, $122-128$.

8. Nikunlassi, Ahti. 2013. Bolevye predikaty v finskom jazyke. Lingvisticheskij bespredel - 2. Sbornik nauchnyh trudov k jubileju A. I. Kuznecovoj. Agranat, Tatiana et al. (eds). Moskva: Izdatel'stvo Moskovskogo universiteta, 255-273.

9. Piccini, Silvia. 2015. Transimpersonal construction in Lithuanian. Towards the emergence of split intransitivity. Baltistica. 2(1), 19-55.

10. Reznikova, Tatiana et al. 2012. Towards a typology of pain predicates. Linguistics. $50,3,421-465$.

11. Seržant, Ilja A. 2013. Rise of canonical objecthood by the Lithuanian verbs of pain. Baltic Linguistics. 4, 187-211.

12. Siiroinen, Mari. 2001. Kuka pelkää, ketä pelottaa. Nykysuomen tunneverbien kielioppia ja semantiikkaa. Suomalaisen Kirjallisuuden Seuran Toimituksia. 844. Helsinki: Suomalaisen Kirjallisuuden Seura.

13. Stolz, Thomas. 2001. On Circum-Baltic instrumentals and comitatives: To and fro coherence. The Circum-Baltic Languages. Typology and Contact. 2. Grammar and Typology. Studies in Language Companion Series. Dahl, Östen, KoptjevskajaTamm, Maria (eds). Amsterdam/Philadelphia: John Benjamins Publishing Company, 591-612.

\section{Kopsavilkums}

Somugru valodās vērojama teikuma galvenā aktanta nekanoniska realizācija (ne-nominatīvs) ar trešās personas verbiem, kas lietojami personas fiziologísko procesu un stāvokḷa nozīmē. Personiskas piederības adesīvs nosauc cilvēku, savukārt partitīvs vai vietas locījumi nosauc vietu, ķermeņa daļu, orgānu, kur cilvēks jūt sāpes vai ko citu fiziolog̣isku. Šì pētījuma mērķis ir locījumu izvēle nolieguma teikumos somu un latviešu valodā, kā arī salīdzinājums ar citām Baltijas areāla valodām. Rakstā galvenā uzmanība veltīta latviešu valodas ķ̣ermeņa daļu nosaukumu locījumiem. Tiek izmantoti autentiski piemēri no latviešu valodas korpusa (daiḷliteratūras) un tulkojumiem no somu valodas, ko veikusi neliela grupa Somijā dzīvojošu latviešu. Rezultāti parāda, ka latviešu valodā fiziologisisko procesu, sāpju vietas izteikšanā dominē nominatīvs, taču trešās personas verbs var būt lietots arī ar lokatīvu un akuzatīvu. Lietuviešu valodā konstrukcija (man skauda galva, DAT + verbs + ACC) līdzīga somu valodai. Starp Baltijas jūras somugru valodām partitīvu (vai citu objekta locījumu, ǵenitīvu) lieto valodas, kas atrodas uz austrumiem no igauņu valodas, kur situācija līdzinās latviešu konstrukcijām. Šajā nozīmē latviešu un igauņu valoda pieder pie vienas valodu grupas. 